increasing incidence of lithium poisoning. It can be prevented by preliminary assessment of renal function and monitoring of the serum lithium especially if there is any change in the patient's condition. As renal excretion is the only route of elimination of lithium, acute renal failure is a serious complication of an already hazardous condition.

\section{Acknowledgments}

We thank Professor A. Polak for his advice, Dr J. Burston for the histological report and the nurses of the Wessex Regional Renal Unit for their skilled attention.

\section{References}

Amdisen, A. \& Skoldborg, H. (1969) Haemodialysis for lithium poisoning. Lancet, ii, 213.
GLesinger, B. (1954) Evaluation of lithium in treatment of psychotic excitement . Medical Journal of Australia, 41, 277.

Hawkins, J.B. \& Dorken, P.R. (1969) Lithium. Lancet, i, 839.

Radomski, J.L., Fuyat, H.N., Nelson, A.A. \& Smith, P.K. (1950) Toxic effects, excretion and distribution of lithium chloride. Journal of Pharmacology, 100, 429.

RoBERTS, E.L. (1950) A case of chronic mania treated with lithium citrate and terminating fatally. Medical Journal of Australia, 37, 261.

Schou, M. (1958) Lithium studies. I. Toxicity. Acta pharmacologica et toxicologica, 15, 70.

Schou, M., Amdisen, A. \& Trap-Jensen, J. (1968) Lithium poisoning. American Journal of Psychiatry, 125, 520.

ThOMSEN, K. \& Schou, M. (1968) Renal lithium excretion in man. American Journal of Physiology, 215, 823.

Verbov, J.L., Phillips, J.D. \& Fife, D.G. (1965) Case of lithium intoxication. Postgraduate Medical Journal, 41, 190.

WILsON, J.H.P., DONKer, A.J.M., VAN DER HeM, G.K. \& WiENKJES, J. (1971) Peritoneal dialysis for lithium poisoning. British Medical Journal, 2, 749.

\title{
Haemolytic anaemia in myelomatosis
}

\author{
C. D. R. Pengelly \\ M.D., F.R.C.P., F.R.C.P.E.
}

\author{
B. K. MONDAL \\ M.B., B.S., D.T.M. \& H.
}

\author{
A. R. BARUA \\ M.B., B.S., D.T.M. \& H. \\ The Grange Hospital, Weaverham, Cheshire
}

\begin{abstract}
Summary
A case of IgA myelomatosis with a haemolytic anaemia is described. No auto-antibodies could be found and the mechanism of the haemolysis was obscure.

Haemolytic anaemia is a rare complication but a search of the literature has revealed a few cases with a comparable shortening of red cell life-span, most without auto-antibodies but some with a positive Coombs' test.
\end{abstract}

\section{Introduction}

Myelomatosis is not a rare disease. Anaemia, leucopenia and thrombocytopenia are common complications, the cause usually being accepted as due to bone-marrow invasion with the abnormal plasma cells. Haemolytic anaemia has been described, but commonly amounts to no more than a mild to moderate degree of shortening of the red cell lifespan. Twelve such cases are described by Cline \& Berlin (1962) with a minimum half-chromium time $\left(\mathrm{T}_{\frac{1}{2}}{ }^{151} \mathrm{Cr}\right)$ of 16 days all with negative Coombs' tests and another by Bowdler \& Prankerd (1962) with a red cell life-span of 15 days. These patients showed no evidence of the presence of auto-antibodies, but Pirofsky (1969) discusses nine patients with autoimmune haemolytic anaemia and myelomatosis and Dacie (1967) refers to seven patients in the literature with myelomatosis and positive Coombs' tests.

We report here a patient with IgA myelomatosis, overt clinical and laboratory evidence of haemolysis, a red cell life-span of about 30 days and an absence of demonstrable auto-antibodies.

\section{Case report}

Mr William D., aged 79 , a retired wireman, previously healthy, was admitted to a local cottage hospital on 15 January 1971 with bilateral bronchopneumonia. This was treated with ampicillin but was slow in resolving and the patient was referred to a chest physician (Dr M. Pemberton) who found anaemia (Hb 7.0 g/100 ml) and a very high ESR (71 $\mathrm{mm} / \mathrm{hr}$ Wintrobe). Plasma proteins showed a high globulin level and immunoelectrophoresis a very high IgA level and sternal marrow examination 
confirmed myelomatosis. The patient was transferred to the Grange Hospital, Weaverham, on 8 February 1971, and afterwards referred to one of us (C.D.R.P.) for further management.

On examination he was pale and dyspnoeic. There was no jaundice or abnormality in the cardiovascular system and BP was $140 / 85 \mathrm{mmHg}$. No enlarged lymph nodes were palpable. Bronchial breathing and coarse rales were present at both lung bases. Urine was normal.

Investigations. $\mathrm{Hb} 6.2 \mathrm{~g} / 100 \mathrm{ml}$. MCHC $26 \%$. WCC $8600 / \mathrm{mm}^{3}$, polymorphs $86 \%$, lymphocytes $12 \%$, monocytes $2 \%$. ESR $71 \mathrm{~mm}$ in $1 \mathrm{hr}$. Blood film showed marked rouleaux formation.

Serum protein $9.6 \mathrm{~g} / 100 \mathrm{ml}$., albumin $1.8 \mathrm{~g} / 100$ $\mathrm{ml}$, globulin $7.8 \mathrm{~g} / 100 \mathrm{ml}$. Electrophoresis showed decreased albumin and a paraprotein band in alpha 2 position. Immunoglobulin estimations showed a very marked increase in IgA (approx. $1000 \mathrm{mg} / 100$ $\mathrm{ml}$, IgG $1000 \mathrm{mg} / 100 \mathrm{ml}$, and IgM $40 \mathrm{mg} / 100 \mathrm{ml}$ (normal).

Serum alkaline phosphatase $16 \mathrm{KA}$ units $/ 100 \mathrm{ml}$. Serum bilirubin $0.5 \mathrm{mg} / 100 \mathrm{ml}$. Blood urea $39 \mathrm{mg} /$ $100 \mathrm{ml}$. Serum electrolytes normal.

Bone marrow: cellular marrow. Normoblasts and myeloid precursors were well represented and there was an occasional megakaryocyte. About $40 \%$ of nucleated cells were of abnormal plasma cell type. The appearances were typical of myelomatosis.

Sputum culture showed normal flora. Faecal occult blood tests were negative on three occasions. Chest X-ray confirmed bilateral bronchopneumonic changes. X-rays of skull and pelvis were normal.

Treatment for the pneumonia consisted of ampicillin $2 \mathrm{~g} /$ day for 7 days. Cyclophosphamide $100 \mathrm{mg}$ daily and oxymetholone $50 \mathrm{mg}$ daily were started on 15 February 1971. On 20 February his haemoglobin was only $4.4 \mathrm{~g} / 100 \mathrm{ml}$, but white cell count and platelets were normal. Three units of whole blood were transfused on 22 February and prednisolone $5 \mathrm{mg}$ thrice daily was started. Cyclophosphamide was reduced to $50 \mathrm{mg}$ daily on 23 February because of a fall in platelets to $83,000 / \mathrm{mm}^{3}$ and they were 117,000 / $\mathrm{mm}^{3}$ on 26 February (Fig. 1). At this time his general condition was satisfactory and he was discharged home on cyclophosphamide $50 \mathrm{mg}$ daily, oxymetholone $50 \mathrm{mg}$ daily and prednisolone $15 \mathrm{mg}$ daily. On March 10 his blood picture showed: $\mathrm{Hb} 7 \cdot 4 \mathrm{~g} /$ $100 \mathrm{ml}$, WCC $8200 / \mathrm{mm}^{3}$, platelets $88,000 / \mathrm{mm}^{3}$. Prednisolone was reduced to $10 \mathrm{mg}$ daily, but oxymetholone $50 \mathrm{mg}$ daily and cyclophosphamide 50 mg daily were continued.

His general condition deteriorated and he was readmitted to hospital on 19 March 1971. He was anaemic and jaundiced, and had gross oedema of both ankles. JVP was raised, pulse $100 / \mathrm{min}$ and regular. BP $170 / 90 \mathrm{mmHg}$. Heart sounds were

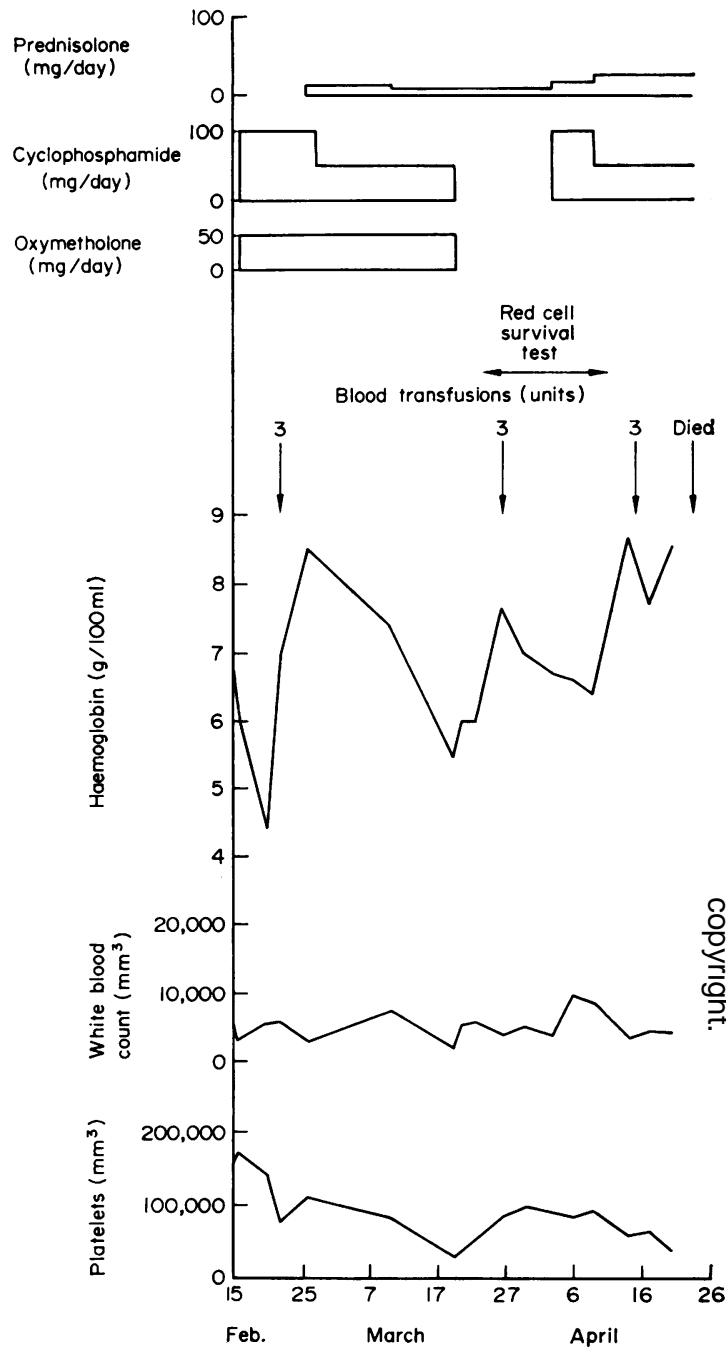

Fig. 1. Summary of progress.

normal. Coarse rales were present at both lung bases. The liver was enlarged to $3^{\prime \prime}$ below the costal margin and the spleen to $2^{\prime \prime}$ below the costal margin. Urine contained an excess of urobilinogen. His heart rapidly became normal with bed rest, digoxin and frusemide therapy, and he was free from oedema or neck vein congestion in 10 days.

Further investigations. $\mathrm{Hb} 5.5 \mathrm{~g} / 100 \mathrm{ml}$, WCC $3000 / \mathrm{mm}^{3}$, platelets $30,000 / \mathrm{mm}^{3}$, reticulocytes $8 \%$. Direct Coombs' test negative. Blood group $\mathbf{O} \mathbf{R h}$ positive. No atypical iso- or auto-antibodies detected in his serum (Manchester Blood Transfusion Service). Haptoglobins (two estimations) $15 \mathrm{mg}$ and $40 \mathrm{mg}$ of $\mathrm{Hb}$ binding power $/ 100 \mathrm{ml}$. Glucose-6-phosphate dehydrogenase in red cells and red cell osmotic 
fragility test normal. Ham's test negative. Liver function tests: Serum bilirubin $2 \cdot 1 \mathrm{mg} / 100 \mathrm{ml}$; thymol turbidity 1 unit; zinc turbidity 10 units; serum alkaline phosphatase $6 \cdot 3 \mathrm{KA}$ units $/ 100 \mathrm{ml}$. Electrophoresis: marked decrease in albumin. Paraprotein in alpha 2 position, slight increase in gammaglobulin. Blood urea $133 \mathrm{mg} / 100 \mathrm{ml}$. Three tests for occult blood in faeces were negative. Mid-stream urine showed coliforms on culture. Electrophoresis of urine: most plasma proteins seen. Paraprotein band seen in alpha 2 position. No sharp band of Bence Jones proteinuria seen in gamma position. Red cell survival test: half-chromium time $\left(\mathrm{T}_{\frac{1}{2}}{ }^{151} \mathrm{Cr}\right)$ was 12 days (equivalent to red cell life-span of about 30 days, calculated by method A of Mollison (1956)). Marrow: cellular marrow with myeloma cells still predominating. No abnormality of erythropoiesis.

Three days after his admission he developed purpuric spots on the abdomen and became more icteric, and blood urea rose to $280 \mathrm{mg} / 100 \mathrm{ml}$. He had a further blood transfusion of 2 units. Cyclophosphamide and oxymetholone were discontinued for a short time but prednisolone was continued $(10 \mathrm{mg}$ daily) (Fig. 1). His general condition remained poor. Blood count: $\mathrm{Hb} 6.8 \mathrm{~g} / 100 \mathrm{ml}$, WCC $5000 / \mathrm{mm}^{3}$, platelets $92,000 / \mathrm{mm}^{3}$. Two weeks later he developed epistaxis and his prednisolone was increased to 30 $\mathrm{mg}$ daily, but he gradually deteriorated and died on 22 April 1971.

Necropsy (Dr H. Allison). There was no congestive heart failure, jaundice or enlargement of lymph nodes, and no gross bony lesions were present. There was mild coronary atheroma with some left ventricular hypertrophy and bilateral terminal bronchopneumonia was present.

The liver, spleen and kidneys were macroscopically normal.

Histological examination of the vertebrae showed extensive infiltration with myeloma cells and the kidneys showed moderate tubular atrophy and hyaline casts in many of the distal tubes.

Liver and spleen were histologically normal.

\section{Discussion}

We have described a patient with myelomatosis, a considerably reduced red cell life-span and clinical evidence of haemolysis. Dacie (1967) emphasizes the rarity of haemolysis in this condition and states that the Coombs' test is rarely positive, though he does refer to seven such cases in the literature. In our patient a thorough search for antibodies both in the serum and adsorbed onto the red cells by the Manchester Blood Transfusion Service was negative, and this seems to have been the case in those patients described by Cline \& Berlin (1962). It is therefore not surprising that there was no response of the haemolysis to prednisolone in our patient.
The mechanism of the haemolysis, as in many cases of malignant disease both haematological and non-haematological is not completely clear (Hyman, 1954; Hyman, Gellhorn \& Harvey, 1956; Pengelly \& Wilkinson, 1962). Auto-immune haemolytic anaemia is most commonly associated with lymphatic leukaemias and malignant lymphomas, and is less usual in association with other forms of malignancy. But it is perhaps surprising that in a malignant disorder of the plasma cells in which there is often a gross alteration in the plasma proteins involving the immunoglobulins, haemolytic anaemia of autoantibody type does not occur more often. This is probably because the protein abnormalities are usually monoclonal in myelomatosis and not polyclonal as are red cell auto-antibodies produced by the lymphatic tissues (Pirofsky, 1969; Hobbs, 1971).

The abnormal globulin in our patient was in the alpha 2 position on paper electrophoresis, although the excess immunoglobulin was clearly of the IgA variety. This phenomenon is known, though not very common, occurring in only $1 \%$ of cases, most being found in the gamma, or, more rarely, in the beta position (Ritzmann \& Levin, 1968; Snapper \& Kahn, 1971).

\section{Acknowledgments}

We are grateful to Dr M. Pemberton for referring this patient to us for further investigation, and to $\mathrm{Dr} \mathrm{H}$. Allison for carrying out the necropsy investigation. Our thanks are also due to Mrs V. McKenzie for preparing the chart, and to Mrs J. White for typing the manuscript.

\section{References}

Bowdler, A.J. \& Prankerd, T.A.J. (1962) Anaemia in the reticuloses. British Medical Journal, 1, 1169.

ClINE, M.J. \& BERLIN, N.I. (1962) Studies of the anaemia of multiple myeloma. American Journal of Medicine, 33, 510.

DACIE, J.V. (1967) The Haemolytic Anaemias: Congenital and Acquired, Part III, 2nd edn., pp. 754-755. Churchill, London.

HoBBs, J.R. (1971) Immunocytoma o' mice an' men. British Medical Journal, 2, 67.

HymaN, G.A. (1954) Studies on anaemia of disseminated malignant neoplastic disease. I. The haemolytic factor. Blood, 9, 911 .

Hyman, G.A., Gellhorn, A. \& Harvey, J.L. (1956) Studies on the anaemia of disseminated malignant neoplastic disease. II. Study of the life-span of the erythrocyte. Blood, 11, 618.

Mollison, P.L.(1956) Blood Transfusion in Clinical Medicine, 2nd edn, p. 139. Blackwell Scientific Publications, Oxford.

Pengelly, C.D.R. \& Wilkinson, J.F. (1962) The frequency and mechanism of haemolysis in the leukaemias, reticuloses and myeloproliferative diseases. British Journal of Haematology, 8, 343.

PIROFSKy, B. (1969) Autoimmunisation and the Autoimmune Hemolytic Anemias, pp. 127-131. Williams and Wilkins, Baltimore.

RitzmaNN, S.E. \& Levin, W.L. (1968) In: Laboratory Notes for Medical Diagnostics, p. 19. Hoechst Pharmaceuticals.

SNAPPER, I. \& KAHN, A. (1971) Myelomatosis. Fundamentals and Clinical Features, p. 52. Karger, Basel. 